\title{
Efficacy of Langhana with Saptamushtika Yusha in the Treatment of Aama in Aamavata with special reference to Rheumatoid Arthritis
}

\author{
Research Article
}

\section{Jasminbegam Momin ${ }^{*}$, Gogate V E ${ }^{2}$}

\author{
1. Post Graduate scholar, 2. Associate Professor, \\ Department of Kayachikitsa, Government Ayurved College, Nanded.
}

\begin{abstract}
In developing societies, the nutritional patterns collectively termed the 'western diet' including high fat and cholesterol, high protein, high sugar and excess salt intake as well as frequent consumption of processed and fast food promote obesity, cardiovascular diseases and metabolic syndrome which are now recognized as due to chronic inflammatory processes in body. According to the ancient Acharyas, above mentioned dietary habits are the common hetus responsible for the Agnidushti and development of diseases like Aamavata. The common signs and symptoms of Aamavata have similarities with Rheumatoid Arthritis which is an autoimmune disorder of unknown etiology. Aamavata has been a challenging problem to the medical field. Various treatment protocols are applied in this disease with partial success. The ancient Acharyas have mentioned the Langhana along with its different possible ways as a first Upakrama for the treatment of Aamavata. In present clinical study, five patients of clinically proven Aamavata were treated with Laghu Aahara Rupi Langhana by using Saptamushtika Yusha for seven days. All clinical Nidanadi Ayurvediya parameters and American College of Rheumatology guidelines for Rheumatoid Arthritis were followed. The assessment of symptoms was done with the help of Disease Activity Score (DAS). Erythrocyte Sedimentation Rate (ESR) which is increased in most of the chronic inflammatory conditions was also investigated. It was observed that there was a marked reduction in ESR along with the considerable relief in signs and symptoms of patient. The results are encouraging and indicate the efficacy of Langhana with Saptamushtika Yusha over Aamavata.
\end{abstract}

Key Words: Aama, Aamavata, Rheumatoid Arthritis, Langhana, Saptamushtika Yusha, DAS, ESR.

\section{Introduction}

Aamavata is a chronic systemic disease involving multiple joints. (1) Among ancient Ayurved Samhitas, Madhav Nidana mentioned the Aamavata as a specific disease entity where Aama and Vata plays a predominant role in the Samprapti of the disease. (2) The disease is mainly due to derangement of Agni which happens due to Ahitakara Aahara-Vihara. (2) It is very common due to the changing lifestyle of dietic and behavioral ways like fast-food, lack of exercise, sedentary routine work. This results in the Agnimandya and subsequently production of Aama which circulates in the body and gets located in the Sandhi causing Sandhishoola, Sandhishotha and Graha. (2) The clinical manifestations of Aamavata can be compared with Rheumatoid Arthritis which is an autoimmune disorder of unknown etiology. (3) The prevalence of Rheumatoid Arthritis is $0.8 \%$ of the population. (4) The onset is most frequent during the $4^{\text {th }}$ and $5^{\text {th }}$ decades of life and women are affected three times more often than men. (4) The characteristic feature of established Rheumatoid

* Corresponding Author:

Jasminbegam Momin

PG scholar,

Department of Kayachikitsa,

Government Ayurved College, Nanded.

Email id - jasminmomin791992@gmail.com
Arthritis is a persistent inflammatory synovitis usually involving peripheral joints in a systemic pattern. (4) It is a common disorder with varied clinical signs and symptoms related to multiple anatomical sites both articular and extra-articular. (5)

Allopathic system of medicine has got an important role to play in overcoming symptoms of articular diseases. (5) The drugs available to overcome the symptoms due to inflammation in the form of NonSteroidal Anti-Inflammatory Drugs (NSAIDs) and the long-term suppression is achieved by the Disease Modifying Anti-Rheumatic drugs (DMRDs). (5) But most of the NSAIDs have gastrointestinal side effects whereas DMARDs have bone marrow, renal and hepatic suppression. (5) Hence the management of this disease is merely insufficient in other systems of medicine and patients are continuously looking with a hope towards Ayurveda. (5)

According to Ayurveda, treatment of Aama has to be done initially for Aamavata. Yogaratnakara have described the Chikitsa Siddhant which includes firstly Langhana then Swedanadi Upakramas. (6) These should be used as per the Rugna Bala and Vyadhi Avastha. Acharyas have also stated Sanshodhana, Pachanadi ten different types of Langhana. (7) This study aims to evaluate the efficacy of Langhana Upakrama in the treatment of Aama in Aamavata by using Laghu Aahara Rupi Langhana in the form of Saptamushtik Yusha. 
Aim

To study the efficacy of Langhana with Saptamushtika Yusha in the treatment of Aama in Aamavata with special reference to Rheumatoid Arthritis.

\section{Objectives}

1. To study the relief in signs and symptoms of Aamavata by Langhana Upakrama.

2. To study the process and duration of Aama Pachana by Langhana.

3. To study the effect on erythrocyte sedimentation rate (ESR)before and after Langhana in Aamavata.

\section{Materials and methods}

\section{Criteria of diagnosis}

Aamavata - Madhava Nidanokta Aamavata Lakshanas (8) -
1.Angamarda
2.Aruchi
3.Trushna
4.Aalasya
5. Gaurava
6.Jwara
7.Apaka

Patient with Sandhishoola and any of 4 of above symptoms were diagnosed as Aamavata.

\section{Rheumatoid arthritis}

Table no. 1 - American College of Rheumatology

(ACR) classification criteria for RA (9)

\begin{tabular}{|l|l|c|}
\hline \multicolumn{1}{|c|}{$\begin{array}{c}\text { Subject } \\
\text { 1.Duration of } \\
\text { symptoms }\end{array}$} & \multicolumn{1}{c|}{ Criteria } & Score \\
\hline $\begin{array}{l}\text { 2. J o i n t } \\
\text { Distribution }\end{array}$ & $\begin{array}{l}\text { More than 6 weeks } \\
\text { 1 large joint }\end{array}$ & 0 \\
\hline & $\begin{array}{l}\text { 2-10 large joints } \\
\text { 1-3 small joints with or } \\
\text { without involvement of } \\
\text { large joint }\end{array}$ & 2 \\
\hline & $\begin{array}{l}\text { 4-10 small joints with or } \\
\text { without involvement of } \\
\text { large joint }\end{array}$ & 4 \\
\hline 3.Serology & $\begin{array}{l}\text { More than 10 joints (at } \\
\text { least 1 small joint) }\end{array}$ & 5 \\
\hline & $\begin{array}{l}\text { Negative RF / CCP } \\
\text { Low RF / CCP }\end{array}$ & 0 \\
\hline 4.Acute phase & High RF / CCP & 3 \\
\hline reactants & $\begin{array}{l}\text { Normal ESR / CRP } \\
\text { Abnormal ESR / CRP }\end{array}$ & 0 \\
\hline
\end{tabular}

A sum of score of equal or more than 6 were diagnosed as Rheumatoid Arthritis.

RF - Rheumatoid Factor;

CCP - Anti Citrullinated Citric Peptide;

ESR - Erythrocyte Sedimentation Rate;

CRP - C Reactive Protein
Method of selection of subjects

Inclusion criteria

- Patients fulfilling the diagnostic criteria of Aamavata and Rheumatoid Arthritis as mentioned above are included.

- Patients between age group of 35-50 years.

- Patients of either sex.

- The patient having the disease for about 2 years and having acute attack in last 15 days.

\section{Exclusion criteria}

- Disease duration more than 2 years.

- Severe deformities with severe ankylosed joints.

- Patients who are steroid dependent.

- Alpa Bala and Alpa Satva patient

- Patient suffering from other systemic illness like diabetic mellitus / hepatic / renal / cardiac illness.

- Pregnant and lactating mothers.

\section{Withdrawal criteria}

- Patient showing any adverse reaction during the treatment.

- Occurrence of any other severe illness or any infectious condition in patient which may interrupt with the pathophysiology of the disease and requires some other medicines.

- If the BSL goes below $70 \mathrm{mg} / \mathrm{dl}$ then he patient were withdrawn from the treatment.

\section{Investigations}

For the purpose of assessing the general condition of the patient of the patient and to exclude other pathologies, the following investigations were carried out

1.RA (Rheumatoid Arthritis) Test

2.CBC - Complete Blood Count

3.BSL - Random (Blood Sugar Level)

4.Urine analysis

5.ESR (Erythrocyte Sedimentation Rate)

\section{Study location}

A clinical study of 5 patients at IPD of our institute.

\section{Study duration and follow up}

Patients were administered with Saptamushtika Yusha at the time of kshudhaprachiti for seven days and assessment of signs and symptoms of patient was done on $0,4^{\text {th }}$ and $8^{\text {th }}$ day.

\section{Treatment protocol}

The patients fulfilling the above diagnostic criteria were admitted at the IPD of our institute. The patients were administered with the Laghu Aahara Rupi Langhana in the form of Saptamushtika Yusha at the time Kshudhaprachiti for seven days. 


\section{Table No. 2 - Composition of Saptamushtika Yusha}

(10)

\begin{tabular}{ll}
$\begin{array}{l}\text { Ingredients } \\
\text { 1.Kulattha }\end{array}$ & Properties \\
\hline 2.Yava & $\begin{array}{l}\text { Laghu, Kapha-Vataghna } \\
\text { Jananam }\end{array}$ \\
3.Kola & Hrudya, Ruchi-utpadaka \\
4.Mudga & $\begin{array}{l}\text { Laghu, Ruksha, Sheeta, Kapha- } \\
\text { Pittaghna }\end{array}$ \\
5.Mulaka & $\begin{array}{l}\text { Tridoshahara, Deepaniya, } \\
\text { Pachaniya, Ruchikara }\end{array}$ \\
6.Sunthi & $\begin{array}{l}\text { Truptighna, Aamavataghni, } \\
\text { Deepaniya, Shoolaprashamaniya }\end{array}$ \\
7.Dhanyaka & Jwaraghna, Trushna nigrahana
\end{tabular}

\section{Method of Preparation (11)}

All the ingredients were taken in $10 \mathrm{gm}$ (total $70 \mathrm{gm}$ ) quantity and Yusha was prepared with $600 \mathrm{ml}$ of jala.

\section{Criteria for assessment}

The results of therapy were assessed on the basis of clinical signs and symptoms mentioned in Ayurvedic classics as well as by worldwide accepted DAS score. Functional capacity was also assessed and laboratory investigations were repeated at the end of the treatment.

Table No. 3 - The scoring pattern adopted for the subjective assessment is as follows

\section{Subjective Criteria \\ Angamarda}

Gradation

No Angamarda

Occasional Angamarda but patient is

able to do routine work

Continuous Angamarda but patient is

able to do routine work

Continuous Angamarda which

hampers the routine work

Patient is unable to do routine work

\section{Aruchi}

Normal desire of food

0

Eating timely without much desire

Desire of food little late than normal

time

Desire of food only after long time

No desire at all

\section{3}

4

\section{Trushna}

Normal feeling of thirst

1

2

Frequent feeling with normal amount

of fluid

Satisfactory quench after increased

intake of fluids but no awaking during

night

Satisfactory quench after increased

intake of fluids with regular awaking

during night

No quench after heavy intake of fluid

\section{Aalasya}

No Aalasya at all

0

Start work in time with efforts

1

Unable to start work in time but

complete it

2

Delay in start of work and unable to

complete it

3

Never able to work and always like to rest

\section{Gaurava}

No feeling of heaviness

Occasional heaviness in the body but can do routine work

Continuous heaviness in the body but can do routine work

Continuous heaviness in the body

which hampers the routine work

Unable to do any work due to

heaviness

\section{Apaka}

Normal digestion

0

Indigestion once or twice in a week in one meal

Indigestion 3-5 times in a week in one meal

Indigestion 3-5 times in a week in

both meal

Indigestion after every meal

4

\section{Objective criteria}

1. Jwara - It was recorded daily at 9am and if the patient was having pyrexia then every four hourly.

2. BSL - It was checked every evening in order to avoid any harm to the patient due to decreased BSL.

3. ESR - As it is increased in chronic inflammatory conditions, it was measured before and after the treatment in order to assess the inflammation.

\section{Disease Activity Score (DAS 28) -}

It was calculated according to the formula -

$0.56 \times \sqrt{\text { number }}$ of tender joints $+0.28 \times \sqrt{\text { number }}$ of swollen joints $+0.70 \times$ Linear number $(\mathrm{ESR})+0.014 \times$ VAS

Table No. 4 - Visual Analogue Score (VAS)

\begin{tabular}{|c|c|}
\hline 0 & No pain \\
\hline $1-20$ & Mild \\
\hline $21-40$ & Uncomfortable \\
\hline $41-60$ & Distress \\
\hline $61-80$ & Intense \\
\hline $81-100$ & Worst \\
\hline
\end{tabular}

\section{Assessment of langhana (12) -}

The assessment of Langhana was done with the help of Samyaka Langhana Lakshanas as stated by Acharya Charaka 
Vata Visarga (Proper excretion of flatus), Mutra Visarga (Proper excretion of urine), Purisha Visarga (Proper excretion of feces), Gatra Laghavata (Lightness in the body) Hrudaya-Udgar-Kantha-Aasya Shuddhi (Feeling of purity in heart, eructation throat and mouth), Tandra (Disappearance of drowsiness), Klama (Disappearance of exertion), Swedaprachiti (Appearance of sweat), Ruchi Utpatti (Appearance of taste for food), Kshudha and Pipasa Sahodaya (Excessive hunger and thirst), Nirvyathe Aantartmani (Contentment).

\section{Results}

The BSL recordings of patients were done on every evening in order to avoid any harm due to restricted diet. It was found that maximum BSL level was on the first day and it was $110 \mathrm{mg} / \mathrm{dl}$. BSL was reduced upto $71 \mathrm{mg} / \mathrm{dl}$ during the course of treatment. But there were no any complaints like giddiness $n$ weakness. All patients were stable during the Langhana Upakrama

Graph no. 1- Graph showing the BSL levels of 5 patients during the course of Langhana Upakrama

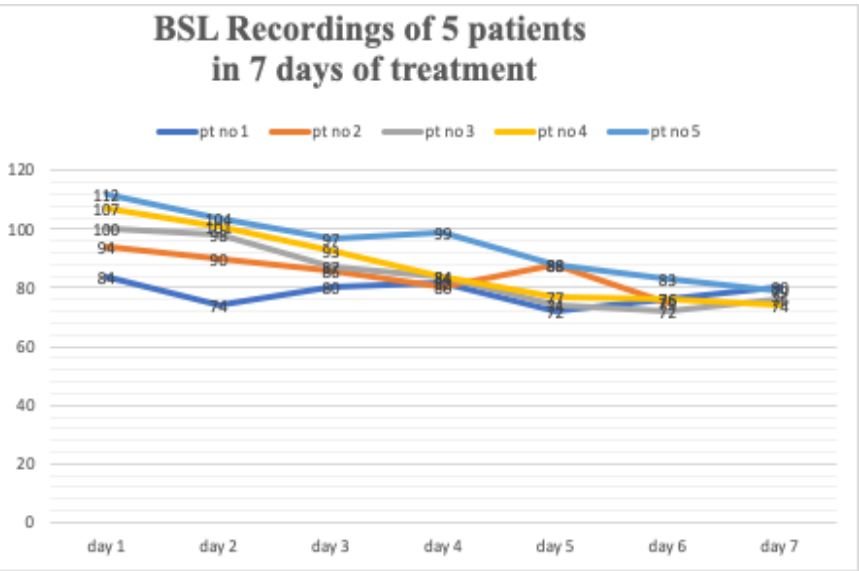

ESR is raised in most of the inflammatory conditions. It was found that after the completion of Langhana Upakrama, there was considerable reduction in shotha and also marked reduction in ESR values.

Table no. 5 - The findings of ESR values of 5 patients before and after treatment are as follows

\begin{tabular}{|c|c|c|}
\hline Pt. No & $\begin{array}{c}\text { ESR }- \text { Before } \\
\text { Treatment }\end{array}$ & $\begin{array}{c}\text { ESR }- \text { After } \\
\text { Treatment }\end{array}$ \\
\hline 1 & $34 \mathrm{~mm} / \mathrm{hr}$ & $24 \mathrm{~mm} / \mathrm{hr}$ \\
\hline 2 & $80 \mathrm{~mm} / \mathrm{hr}$ & $36 \mathrm{~mm} / \mathrm{hr}$ \\
\hline 3 & $60 \mathrm{~mm} / \mathrm{hr}$ & $50 \mathrm{~mm} / \mathrm{hr}$ \\
\hline 4 & $62 \mathrm{~mm} / \mathrm{hr}$ & $54 \mathrm{~mm} / \mathrm{hr}$ \\
\hline 5 & $17 \mathrm{~mm} / \mathrm{hr}$ & $10 \mathrm{~mm} / \mathrm{hr}$ \\
\hline
\end{tabular}

The assessment of signs and symptoms of patients was done with the help of DAS 28 Score. The maximum difference between the score before and after the treatment was 32.44 .
Table no. 6 - DAS 28 Score of 5 patients before and after treatment

\begin{tabular}{|c|c|c|}
\hline Sr. No. & $\begin{array}{c}\text { DAS Score }- \\
\text { Before Treatment }\end{array}$ & $\begin{array}{c}\text { DAS Score }- \text { After } \\
\text { Treatment }\end{array}$ \\
\hline 1 & 28.05 & 18.96 \\
\hline 2 & 61.32 & 28.88 \\
\hline 3 & 45.92 & 37.45 \\
\hline 4 & 46.61 & 39.64 \\
\hline 5 & 14.95 & 8.91 \\
\hline
\end{tabular}

Patients were having Samyaka Mala-Mutra Pravartana, Ruchiutpatti, Samyaka Kshudhapravartana and feeling of Laghavata.

\section{Discussion}

As no fuel was provided to the hypofunctioning Jatharagni, it was excited gradually. Langhana helps in the excitation of Jatharagni which causes Pachana of the undigested intermediate product, that is, Guru, Pichchila and Stabdha Aama. Hence, the patients were having feeling of Laghavata and free movements of joints. There was decrease in the complaints of Sandhishoola, Sandhishotha and Graha. The patients became able to do their routine work independently with minimum efforts.

The pathology of Aamavata originates in Aamashaya due to poor digestion in the presence of Mandagni. Thus Aamavata is not the disease of joints but it is a disease having Udbhava Sthana in the Aamashaya and Abhivyakti at the joints. Thus, by gradual excitation of Jatharagni with the help of Langhana Upakrama, Pachana of Aama is achieved and its further formation is restricted.

Due to cleaning of Srotomarga, Vatanulomana was there and Ushma was restored to its normal state. Thus, there was a considerable decrease in the complaints of Jwara.

All the ingredients of Saptamushtika Yusha have Deepana, Pachana, Ruchi utpadaka properties. This also helps in the digestion of Aama. This improves Ruchi, improves Kshudha and helps in Samyaka MalaMutra Pravartana. Thus, Samyaka Langhana Lakshanas were also achieved. Though the Kulattha is having Amlapittajanana property, it is used as one of the most important ingredient in this Kalpa but no patient had complained of the Amlapitta. This may be due to balancing effect of other ingredients.

Everyday BSL recording were done in order to provide any emergency medication in case of decreased sugar level. But all the five patients were stable as Saptamushtika Yusha was helping in improving the Ruchi and Pachana of Aama. So Samyaka Kshudhapravartana was there and all patients were taking Yusha as per their Kshudha. Hence there was no need of any emergency medicine.

ESR is raised in most of the inflammatory conditions. It was found that there was a marked reduction in ESR values after completing the Laghu Aahara Rupi Langhana Upakrama. This may be due to Langhana which helps in Pachana of Aama and reduction of Shotha. 
The assessment was done with the help of DAS

28 Score. Patients have marked reduction in the complaints of joints swelling and tenderness and the score was considerably reduced. After completing the Laghu Aahara Rupi Langhana Upakrama, there was Pachana of Guru, Pichchila and Stabdha Aama, hence joints were having considerable reduction in swelling and tenderness. Patients were having free movements of joints, hence the DAS score reduced after the treatment.

Thus there was no worsening of signs and symptoms and patients were treated by Laghu Aahara Rupi Langhana by doing Pachana of Aama with the help of Saptamushtika Yusha. Then the patients were further treated with Swedanadi Upakrama as per the Vyadhi Avastha.

\section{Conclusion}

Langhana helps in the digestion of Aama and stops its further formation. The ingredients of Saptamushtika Yusha have Deepana-Pachana properties which facilitates in achieving the effects of Langhana. Patients were having Ruchiutpatti, Samyaka Kshudhapavartana, Samyaka Mala- Mutra Pravartana and feeling of Laghavata after completing the Langhana Upakrama. They became able to do their routine work independently with minimum efforts. Thus, the holistic approach by Ayurvedic Chikitsa Siddhanta is helpful in the treatment of Aama in Aamavata.

\section{References}

1. Saroj K. D., Sudhaben N. V. Clinical study on Amavata (Rheumatoid Arthritis) with Simhanada Guggulu and Shatapushpadi Lepa. International Journal of Ayurvedic Medicine. 2014, 5(1), page 70 searched on 12/11/2019 at $7.30 \mathrm{pm}$.
2. Yadunandana Upadhyay. Madhava Nidanam of Acharya Madhava.3rd edition. Varanasi; Chaukhambha Prakashana; 2013, page 508-509.

3. Clinical Research Protocols for Traditional Health Sciences (Ayurveda, Siddha, Unani), Central Council for Research in Ayurveda and Siddha, Department of AYUSH, Ministry of Health and Family Welfare, Govt. of India, New Delhi, 2010.

4. Fauci, Braunwald, Kasper, Hauser, Longo, Jameson, Loscalzo. HARRISON'S Principles of Internal Medicine. volume 2. 17th edition. Mc Grave Hill Companies. 2008, p 2083.

5. Pandey S. A., Joshi N. P., Pandya D. M. Clinical efficacy of Shiva Guggulu and Simhanada Guggulu in Aamavata (Rheumatoid Arthritis), International Quarterly Journal of Research in Ayurveda. 2012 Apr-June; doi:10.4103/0974-8520.105246; searched on $4 / 10 / 2019$ at $8.40 \mathrm{pm}$.

6. Shrilakshmipati Shastri. Yogaratnakara. Varanasi; Chaukhambha Prakashana; page 566.

7. Ramharsha Singh. Charak Samhita of Acharya Agnivesha. Varanasi; Chaukhambha Surbharati Prakashana; 2017, page 121.

8. Shri Yadunandan Upadhyay. Madhava Nidanam of Acharya Madhava. Varanasi; Chaukhambha Prakashana; 2013, page 511.

9. Munjal Y.P., API Textbook of Medicine, $9^{\text {th }}$ edition, Jaypee Brothers, Volume 2, page 1833.

10. Bramhanand Tripathi. Sharangdhara Samhita of Acharya Sharangdhara. Varanasi; Chaukhambha Surbharati Prakashana; 2015, page 104.

11. Bramhanand Tripathi. Sharangdhara Samhita of Acharya Sharangdhara. Varanasi; Chaukhambha Surbharati Prakashana; 2015, page 104.

12. Ramharsha Singh. Charak Samhita of Acharya Agnivesha. Varanasi; Chaukhambha Surbharati Prakashana; 2017, page 121. 